\title{
THE IMPLEMENTATION INCLUSIVE EDUCATION: IMPLICATION FOR CHILDREN WITH SPECIAL NEEDS IN TAMANSARI ELEMENTARY SCHOOL IN YOGYAKARTA
}

\author{
Nurul Hidayati Rofiah ${ }^{\otimes}$, Dara Sudiraharja ${ }^{2}$, and Ediyanto ${ }^{3}$ \\ 1,2 3 Graduate School for IDEC Hiroshima University, Japan. Department of Islamic Education \\ STAIM Blora Blora, Indonesia, Indonesia.
}

凶d191200@hiroshima-u.ac.jp, darasudiraharja@gmail.com, Ediace09@yahoo.co.id.

\begin{abstract}
Many children with special needs do not have access to education. The number of children with special needs who have to attend primary school is still very minimal. Most schools only provide regular education, while students are ordinary children who do not need special needs in their education. This study aims to describe the model of implementing inclusive education in Tamansari Elementary Schools and find problems in implementing inclusive education. The research method is qualitative interactive. Data collection use interviews, observation, and documentation methods. Data analysis uses interactive analysis. The results showed that Tamansari Elementary School used a full class model. Identification and assessment are carried out before accepting students with special needs. This is done to gather information before preparing a learning program for students with special needs according to their learning needs. The curriculum is modified to suit the children's needs. The special teacher comes from a special school near the location. Supporting factors are the acceptance of children with special needs, local government support in the implementation of inclusive education, while obstacle factors in the application of inclusive education are limited special teachers and limited infrastructure.
\end{abstract}

Keywords: special needs; inclusive education; diversity.

How to Cite:

INTRODUCTION According to Permendiknas No. 70 of 2009 article 3, it is mentioned that every student who has physical, emotional, mental, and social disabilities or has the potential for intelligence and unique talents has the right to participate in inclusive education at specific educational units according to their needs and abilities. Children with special needs is a term used to refer to children who have their uniqueness in types and characteristics.

Children with special needs are children with special characteristics that are different from children in general without always showing mental, emotional, or physical disabilities. In Government Regulation, No. 17 of 2010 Article 129 paragraph (3) stipulates that students with disabilities consist of students who are visually impaired, deaf, mentally retarded, mentally disabled, conduct disorder, learning difficulties, slow learning, autism, have motor impairments, become victims of narcotics abuse, illegal drugs, and addictive substances, and has multiple disorders.

Data of children with special needs (Ministry of Education and Culture, 2010) is 
approximately 1,544,184 children, it is predicted there are around 330,764 children $(21.42 \%)$ are children with special needs in the age range of 5-18 years in 2010. Of the 330,764 children, they have received education services in Special Schools (SLB) or Inclusive Schools, from Kindergarten to Junior High Schools totaling 85,737 children (25.92\%). So there are still around 245,027 children (74.08\%) who do not have access to education [1].

The number of children with special needs who have attended primary school is only $0,00018 \%$, and junior high school is only $0,00012 \%$ of the total school-age children. While the percentage of schools providing an inclusive education for the elementary school level is $0.39 \%$ and the junior high school level is $0.25 \%$. From these data, it can be concluded that very few children with special needs are getting educational services while education is the right of every child, including children with special needs. They have the same right to obtain a quality education and are not discriminated against.

All children can take lessons without seeing their abnormalities and disabilities. Through inclusive education, children with disabilities are educated together with other children to optimize their potential [2]. With inclusive education, schools and teachers can learn to respond to different learning needs. Differences are a reinforcer in improving the quality of learning for all children. The main obstacle for children with disabilities to progress, including in accessing education as high as possible, is not on their disabilities but on the social acceptance of the community.

One of the schools that have implemented inclusive education is Tamansari Elementary School. This school is one of eight schools designated as inclusive elementary schools by the Yogyakarta Special Region Province Education Office. It is becoming an inclusive school such as Tamansari Elementary School requires a variety of things that are different from other schools. As is the case with public schools, Tamansari Public Elementary Schools carry out learning in the same system as public schools. But Tamansari Elementary School turned out to be willing and able to accept and accommodate students with special needs. This school has experience in fostering students with special needs who are united with normal students.

Being an inclusive school is indeed not easy. At least, schools must prepare themselves with innovations so that children with special needs can follow the learning process well [3]. These innovations start from the introduction of inclusive education, identification of children with special needs, curriculum development, teaching methods, instructional media, teacher competencies, assessments, to academic and non-academic services that must be arranged in such a way and certainly requires a significant amount of time and money [4].

The school is a place to internalize the values of diversity. Schools must provide classroom conditions that are warm, 
friendly, accept diversity, and respect diversity [5]. Schools must also be ready to manage heterogeneous classes by applying curriculum and individualized learning [6]. In addition, teachers are required to collaborate with other professions or resources in planning, implementing, and evaluating. Teachers are required to involve parents meaningfully in the education process so that learning can run effectively and efficiently. Therefore, this study aims to describe the implementation model of inclusive education used in Tamansari Elementary School, find out the implications of inclusive education with learning activities in Tamansari Elementary School, and find out the problems faced by schools in implementing inclusive education.

\section{METHOD}

This type of research is interactive qualitative research with a pedagogical approach. The phenomenon studied was the application of the inclusive education model in Tamansari Elementary School. The subject of this research informant was the principal of Tamansari Elementary School, as the leader and policymaker of the school, the deputy head of the school in the field of curriculum, class teacher, subject teacher, and Special Supervising Teacher, Tamansari Elementary School students

Data collection methods use observation, interviews, and documentation. In this study, things that will be observed are teaching-learning activities in the classroom, the social interaction of students of children with special needs with other students in school, and the classroom structuring system. In this study, things that will be interviewed include the leadership of school principals in inclusive schools, school curricula, the determination of teaching teachers in the classroom, evaluation of the learning outcomes of students with special needs, school administration, and the views of students with special needs children attending the inclusive school. Documents needed in this study include new student admission documents, assessment documents, learning design documents, student documents, curriculum documents, teaching and educational staff, Special Teacher Teacher data, and other data that support this research.

The data analysis method uses descriptiveanalytic. The data analysis step used in this study refers to Miles and Huberman's interactive model analysis, namely the stage of data reduction, data presentation, data verification, and data inference [7].

\section{RESULTS AND DISCUSSION}

\section{A. The Model of Application of Inclusive Education in Tamansari Public Elementary School}

There are several models of implementing inclusive education, 
including 1) full inclusion, where students with special needs learn together with other students all day with the same curriculum. 2) regular classes with clusters, where students with special needs learn together with other students in the special group. 3) regular classes with pull out systems, where students with special needs learn together with other students, and some other times they are separated from class to the counseling room to study and get guidance from specialized teachers. 4) regular classes with clusters and pull out systems, where students with special needs learn together with other students in the special groups some times they are separated from class to the counseling room to study and get guidance from specialized teachers. 5) special classes with some integration, where students with special needs learn from specialized teachers in the individual rooms, and some other time, they learn together with regular students in the regular classes. 6) full special classes, where students with special needs learn from special teachers in the special rooms in the regular school [8]. Each inclusive school can choose which model will be applied, mainly depending on the number of children with disabilities to be served, the type of disability of each child, gradation (level) of children's abnormalities, availability and readiness of teaching staff, and the available infrastructure.

\section{Learners}

Taman Sari State Elementary School accepts children with special needs and regular children. School identified and assessed in accepting students with special needs. The identification of children with special needs to recognize students' abnormalities and the accompanying symptoms. Identification is based on observable symptoms such as physical symptoms, behavioral symptoms, and learning outcome symptoms. Identifying possible students to work closely with those closest to them: parents, psychologists, therapists, and teachers who are always in contact with children.

The next stage is the assessment of students with special needs. Assessment is a process of gathering information about children as a whole concerning conditions and characteristics of abnormalities, strengths, and weaknesses as a basis for the preparation of learning programs so that the process of implementing learning will be following their conditions and needs. Tamansari Elementary School in conducting an assessment in collaboration with the Child Growth Clinic Dr. Sardjito and the psychology and education department of Special School Bantul 1.

2. Curriculum

Based on data from students with special needs in Taman Sari Public Elementary School, 34 students have 
various obstacles. These obstacles include vision, obstacles in hearing, physical barriers, and slow learning. As presented in the table below.

Table 1. List of students with special needs

\begin{tabular}{lc}
\hline \multicolumn{1}{c}{ Type } & Total \\
\hline Low vision & 1 \\
Deaf & 1 \\
Physical disabilities & 1 \\
Intellectual disabilities & 2 \\
Slow learner & 31 \\
\hline
\end{tabular}

In developing the curriculum, Tamansari Elementary School uses duplication and modification models. The first model used in developing the curriculum is the duplication model. Duplication develops or enforces curricula for students with special needs similar to curricula used for students in general or regular. This duplication model is applied to four main components of the curriculum, namely, objectives, content, process, and assessment. The duplication model is applied for children with special needs who do not experience barriers such as blindness, hearing impairment, and physical impairment. The objectives, materials, and assessment of learning did not change but needed modifications in the learning process related to methods and media in presenting the information. The second model that is applied is the modification model. The applicable curriculum has been changed to suit students with special needs. Modifications are applied to four main components, namely learning objectives, materials, processes, and assessment.

3. Educators

Educators are professional educators who have the main task of educating, teaching, guiding, directing, training, assessing, and evaluating students. Educators consist of class teachers based in primary schools who are determined based on qualifications in accordance with the conditions set by the school, subject teachers who teach specific subjects (religious education and physical education), and special teachers. Based on the Decree of the Head of the City Education Office number 188/1029, there are three special teachers in Taman Sari Elementary School. Class teachers, subject teachers, and special assistant teachers together compile educational assessments and build a coordination system in carrying out the mentoring of children with special needs in Tamansari Schools. The ratio of special companion teachers to children with special needs is not ideal. The comparison between special teacher assistants with children with special needs is 1: 8 . One of the obstacles faced by teachers in the implementation of inclusive education is the lack of educators who understand the characteristics and needs of students with special needs, difficult to 
modify curriculum and lack special supervisors [9].

\section{Learning Activities}

Based on the results of interviews with the Principal of Tamansari Elementary School, the inclusive education model implemented in schools is a full class model. Where students with special needs learn with regular students throughout the day in regular classes. Students at Taman Sari Public Elementary School can accept the existence of children with special needs like ordinary friends without discrimination when the learning process is in the classroom or outside the classroom.

Learning activities in Tamansari Elementary School consist of planning and implementation activities. Matters considered in learning planning are related to the learning program design model used classroom management planning, planning of teaching materials, strategies and methods to be used, learning procedures, learning resources, and assessment models used. The lesson plan used is a modified lesson plan that is tailored to the needs of children in school.

While learning implementation
activities include apperception, presenting learning material, implementing methods, and encouraging students to be actively involved. Teachers and all students are open, tolerant, and accept children with special needs without stigma/labeling, which reduces the selfesteem of children with special needs.

5. The Assessment

The assessment of learning is modified according to the barriers of children with special needs. children with special needs who do not have positions of intelligence, the minimum mastery criteria are the same as regular students. Only modifications are made in the assessment process; for example, for blind children, the test is done orally.

Students who complete their education and pass examinations according to national standards get a diploma that is issued by the government. Whereas students who have disabilities who complete education based on a curriculum developed by an education unit under the national education standard get a letter of graduation study (STTB) whose bloc is issued by the education unit in question. STTB can be used to continue education at a higher level, either in the education unit that organizes inclusive education or special education units.

6. Infrastructure Facilities

Facilities and infrastructure are still limited. Even though such conditions of buildings and classrooms have been adjusted so that it is accessible for children with special needs who experience physical disabilities, such as physical disabilities and the blind. Some learning equipment is also modified according to the needs of children. For example, in textbooks that enlarge to 
facilitate children who experience low vision.

In implementing inclusive education, it does not require all children with disabilities to be in regular classes at all times with all subjects (full inclusion). Some children with disabilities can be in a special class or therapy room because the gradation of the disorder is quite substantial. Even for children with disabilities whose gradations are severe, it may be more time to be in a special class at a regular school. Then, for those whose gradations the disability is very heavy, and is not possible in regular schools, it can be distributed to special schools.

B. Implications of Inclusive Education in Learning in Tamansari Elementary School

Inclusive education has a positive impact on learning in Tamansari Elementary School. It can be seen in the following cases.

1. Class teachers are responsible for creating a classroom atmosphere that fully accommodates all children by emphasizing social atmosphere and behavior that respects differences. This is because inclusive education is an education that can create and maintain a classy society that is warm, accepts, and appreciates differences [10]

2. The accommodative curriculum for students with special needs to be developed by its potential. The paradigm shift from a competitive learning approach to a cooperative learning approach that involves collaboration between students.

3. Application of active learning methods in inclusive classrooms and buddy systems. This creates interactive learning and collaboration between educators and their friends.

4. Cooperation between teachers and other professions in one team is needed, such as with parents, special assistant teachers, psychologists, pediatricians, therapists, and so on.

5. Parental involvement in the preparation of individual teaching programs and assistance in learning at home.

\section{Supporting and Obstacle Factors in the Implementation of Inclusive Education}

Some supporting factors in the application of inclusive education in Tamansari Elementary School include:

1. Students in Tamansari Elementary Schools, in general, are able to accept the presence of children with special needs to attend learning in the same class. Acceptance of children with special needs is an initial capital in applying the values of inclusiveness [11]. 
2. Local government support in providing comprehensive training at Taman Sari Public Elementary School. Socialization related to diversity and intense inclusive is one of the opportunities for the success of inclusive education [12].

3. Parents provide a special assistant teacher because of the limitations of the special assistant teacher from the school. Parents play an important role in the education of children with special needs. Both moral and spiritual support both at home and at school are needed.

Some inhibiting factors in the application of inclusive education are:

1. The number of special teachers is still limited. There are only three special assistant teachers, one of whom is a special teacher in Bantul who only bashes twice a week. The ratio of children with special needs to special assistant teachers is not balanced. There are 34 students with special needs, with only three special teachers

2. Infrastructure facilities are still inadequate. Limited facilities and access for children with special needs at Taman Sari Public Elementary School.

3. Mindset teachers and parents still consider that children with special needs are not able to follow the learning process in regular schools.

\section{Conclusion}

The Tamansari Elementary School implementation of inclusive education uses the full class model. Students with special needs received are identified, and an assessment is carried out to gather information before a learning program is prepared for students with special needs so that it matches their learning needs. The curriculum used is an educational unit curriculum that is modified according to need. Classroom teachers are assisted by special tutors from a special school in classroom learning. Implementation supporting factors are accepted from students who do not have special needs, parents, teachers, and all components of the school community towards children with special needs, local government support in the application of inclusive education. While the inhibiting factors in the application of inclusive education are the lack of special assistant teachers and limited infrastructure. In implementing inclusive education, it is indeed needed a joint commitment between parents, teachers, students so that this inclusive education can run as expected and aspired. Inclusive education is a very strategic step that gives attention to children with special needs to be able to get an education in regular schools. Inclusive education hopes to be childfriendly education and education that is free for children with special needs.

\section{ACKNOWLEDGMENTS}

We thank Kopertis $V$ as a funding sponsor and Ahmad Dahlan University for 
supporting the facilities. We extend our warmest thanks to participants and schools who have been involved in the study.

\section{REFERENCES:}

[1]Kemdikbud, "bahan pendidikan inklusif", http://bahanpendidikaninklusif

[2]Supriyanto, D.Teacher's Attitude Towards Inclusive Education: A Literature Review. Indonesian Journal of Disability Studies, 2019, Vol 6 No 1, pp 29-37

[3]Tarnoto, Nissa. Permasalahanpermasalahan yang dihadai sekolah enyelenggara pendidikan inklusi pada tingkat SD. Humanitas: Jurnal Psikologi Indonesia, 2016, Vol 13 No 1, pp 50-61

[4]Lisdiana, Supriyanto \& Tarsidi. Sikap Guru terhadap Pendidikan Inklusi kecenderungan internasional. JASSI ANAKKU, 2018, Vol 19 No 1, pp 1-10

[5]Abosi, O \& Koay, T.L. Attaining Development Goals of Children with Disabilities: Implication for Inclusive Education. International Journal of Special Education, 2008, Vol 23 No 3, 1-10

[6]Fitria, R. Proses Pembelajaran dalam Setting Inklusi di sekolah dasar. Jurnal Imliah Pendidikan Khusus, 2012, Vol 1 No 1, 90-101
[7]Miles, M.B dan Huberman, A M.. Analisis Data Kualitatif. Jakarta: UI-Press. 1995.

[8]Rudiyati, S. Potret Sekolah Inklusif di Indonesia. Prosidiing National conference Asosiasi Kesehatan Jiwa dan Remaja (AKESWARI) Yogyakarta, 2011.

[9]Suryani. Persepsi Guru Regular Terhadap Penyelenggaraan Pendidikan Inklusif di SMP Negeri Kodya Surabaya". Thesis. FIP jurusan PLB Unesa. 2014.

[10]Rofiah, Nurul Hidayati \& Ina Rofiana. Penerapan Metode Pembelajaran Peserta Didik Slow Learner, NATURALISTIC: Jurnal Kajian Penelitian Pendidikan dan Pembelajaran, 2017, Vol 2 No 1, 94107.

[11]Kurniawan, Muhammad Ragil dan Nurul Hidayati Rofiah. (2018). Acceptability of children with special needs in inclusive elementary school. Vol 12 no 4, 589596. Hasyim, Yahya. Pendidikan Inklusif di SMK 2 Malang. Jurnal Kebijakan dan Pengembangan Pendidikan, 2013, Vol 1 No 2, 112121. 